\title{
Privateering in Medieval England ${ }^{1}$
}

\author{
Maryanne Kowaleski, Fordham University
}

I first became interested in the size and impact of the economic profits that might have accrued to medieval privateers when doing research on the maritime economy of southwestern England, particularly Devon and Cornwall. The late medieval prosperity of the West Country is very marked, especially in comparison with the economic decline and decay evident in most other English regions, particularly the eastern port towns, which experienced real difficulties in this period. I have explored the sources of the West Country's maritime growth in a variety of publications on shipping, fisheries, and trade, but I've always had a sneaking suspicion that the well-known proclivity of Devon and Cornish mariners for privateering and piracy must have infused significant cash into the local maritime economies. Individual privateers such as Richard Spicer of Plymouth, for example, acknowledged before the court of Admiralty that he had captured goods worth well over $£ 5000$, while John Hawley's built up enough wealth to acquire fifteen ships and estates in both Devon and Cornwall, even though his maritime trading ventures were not on a particularly impressive scale. ${ }^{2}$ Regular and substantial windfalls from privateering might help to explain why, for example, a tiny port like Dartmouth (which ranked only $88^{\text {th }}$ among urban wealth in 1334) became the leading supplier of ships in the late medieval English carrying trade. Dartmouth, in fact, along with Fowey and Plymouth was singled out in the Libelle of Englyshe Polycye, a 1436 poem advocating the importance of sea power, because they were such effective harrassers of enemy shipping. ${ }^{3}$ C. L. Kingsford recognized the entrepreneurial spirit of the

\footnotetext{
1 This paper was first given at the Fifth International Congress of Maritime History in Greenwich, June 2008. I have added some material since then, but the footnotes in particular still need to be brought up-to-date. For example, the paper needs to take account of Thomas Heeboll-Holm, Ports, Piracy and Maritime War: Piracy in the English Channel and the Atlantic, c. 1280-c. 1330 (Brill, 2013). Abbreviations used: CCR = Calendar of Close Rolls; CPR=Calendar of Patent Rolls; TNA=The National Archives, Kew.

${ }^{2}$ Calendar of Inquisitions Miscellaneous, 1399-1401, 349 (for Spicer); see also his entry in The House of Commons 1386-1421, ed. J.S. Roskell, Linda Clarke and Carole Rawcliffe (History of Parliament Trust, 1992). For Hawley, see his entry in The Oxford Dictionary of National Biography, under 'John Hawley;' Dorothy Gardiner on Hawley in Transactions of the Devonshire Association (1966); Stephen Pistono, "Henry IV and the English Privateers," English Historical Review 90 (1975), 322-30; ; idem, "Henry IV and John Hawley, Privateer, 1399-1408," Transactions of the Devonshire Association 110 (1979), pp. 145-63, Hawley, John I, in: The House of Commons, ed. Roskell et al. III, pp. 328-331, and the relevant documents in Dartmouth, ed. H. R. Watkin (Torquay: Devonshire Association, 1935), listed under 'Hawle'.

${ }^{3}$ Libelle of Englyshe Polycye: A Poem on the Use of Sea-power, 1436, ed. George Warner, Oxford, 1926, p. xxx. For Dartmouth, see Maryanne Kowaleski, "Shipping and the Carrying Trade in Medieval Dartmouth," in Von Nowgorod bis London: Studien zu Handel, Wirtschaft und Gesellschaft im mittelalterlichen Europa. Festschrift für Stuart Jenks zum 60. Geburtstag, ed. Marie-Luise Heckmann and Jens Röhrkasten (Göttingen: V\&R Unipress, 2008), pp. 465-87 and idem, "Port Towns in Fourteenth-Century Devon" in The New Maritime
} 
West Country mariners in vivid detail in arguing that their piratical activities formed a "school for seamen" that was exploited in many maritime sectors, including exploration to the New World. ${ }^{4}$

When I first started work on this project, my intention was to focus on the economic and social role of sanctioned privateering by examining the men who received licenses to harass and plunder enemy vessels in the fourteenth and fifteenth centuries. I planned, as I have done on many occasions before, to take a prosopographical approach to the privateers and their activities by collecting data on each known privateer for a computer database so that I could create a kind of collective biography of privateers and their activities. ${ }^{5}$ I aimed to provide at least preliminary answers to such questions as: what social background did privateers come from? What was their geographical distribution across England; were they indeed more common in the West Country? What was their chronological distribution; do we see a heyday of Cinque Ports privateers in the thirteenth and early fourteenth century? Were their profits converted into cash, and what did individual privateers do with what they made? Michel Mollat and Poul Adam actually posed (but did not answer) many of these questions decades ago, but few medievalists have responded to their call for action. ${ }^{6}$ As you can perhaps tell from my wistful tone here, things did not exactly turn out as planned. I ran into two significant problems when I began doing research for this paper. The first is that I did not have much guidance from previous scholarship: very few historians have written about privateering in medieval England, so I have had to do a lot of work from the ground up.

History of Devon, eds. M. Duffy, Basil Greenhill, Stephen Fisher, David Starkey, and Joyce Youings (London and Exeter: Conway Press and University of Exeter, 1992), pp. 62-72.

${ }^{4}$ C. J. Kingsford, Prejudice and Promise in Fifteenth Century England (Oxford, 1925; reprint 1962)

${ }^{5}$ I used Microsoft Access to create a relational database with two linked tables: the Privateering table recorded information about individual incidents of privateering (dates, location, duration, target, the requestor and granting authority if authorized by a letter of marque, and data on prize taken and costs incurred), while the Privateers table kept track of each individual named as in the privateering incident (name, occupation/role on board ship, home residence, and the shipname, homeport, and shipmaster). I used the database to record 60 Privateering incidents in the $15^{\text {th }}$ century that names 41 privateers. I then added another 141 references to letters of marque or reprisals (mostly in the $14^{\text {th }}$ and early $15^{\text {th }}$ century). See below, p. 4 for examples of the types of sources I employed. For a recent example of my application of this methodology, see M. Kowaleski, "The Assimilation of Foreigners in Late Medieval Exeter: A Prosopographical Analysis' in Resident Aliens in Medieval England, ed, Nicola McDonald, W. Mark Ormrod, and Craig Taylor (Turnhout: Brepols, 2017), pp. 163-79.

${ }^{6}$ M. Mollat, "Guerre de course et piraterie la fin du moyen ge: aspect économiques et sociaux. Position des probèmes," Hansische Geschichtsblatter 90 (1972): 1-14. See also "De la piraterie sauvage à la course réglementée (XIVe-Xve siècle)," Mélanges de l'école française de Rome, 87 (1975), 7-25; The essays in Course et Piraterie, ed. M. Mollat, 3 vols. (Paris, 1975) were designed as a response to his queries, most of which relate to political economy. See also Poul Adam, "Typologie de la course et la piraterie," ibid., 917-55, and M. Mollat, "Essai d'orientation pour l'étude de la guerre de course et de la piraterie," Annuario de Estudios Medievales, 10 (1980): 741-50. 
There is no sustained study for medieval Britain that matches, for instance, the relatively abundant literature on la course in France and the Mediterranean, or the Vitalienbrüder in the Baltic, or the impressive recent scholarship on eighteenth- and nineteenth-century Atlantic privateering. ${ }^{7}$ When scholars of medieval England have turned their attention to the subject, they have focused more on the fuzziness of the legal line between privateering and piracy than on distinguishing how contemporaries viewed the relative profitability of these two forms of commerce-raiding. And far more attention has been paid to privateers who went beyond the limits of their crown licence in attacking friendly shipping, than to what happened when privateers worked within the purview of the licence. We do know a lot about the political implications of English privateering, thanks to the work of C. J. Ford and Stephen Pistono, and an even older legal history approach to the history of prize jurisdiction (by Reginald Marsden and Dorothy Gardiner) also provides useful data. ${ }^{8}$ Ford convincingly argues that the rampant "piracy" identified by Kingsford and others was actually a carefullythought out policy on the part of the English crown, which was able to rein in the privateers when it wanted. Pistono, however, tends to be quicker to label hostile attacks as piracy or unauthorized violence than as privateering. ${ }^{9}$ Colin Richmond's work on the late middle ages is valuable for details on war, but he consciously avoids using the word "privateer" and often conflates "private initiative" with "piracy." 10 J. W. Sherborne also avoids using "privateer" in discussing sea warfare during the Hundred Years War; like Richmond, Sherborne instead concentrates on ships and men in naval service. G. V. Scammell, a major contributor to our understanding of English conflict at sea during the early Tudor Age, is also reluctant to label

\footnotetext{
${ }^{7}$ See, for example, the essays in Mollat, ed., Course et Piraterie; Frederic L. Cheyette, "The Sovereign and the Pirates, 1332," Speculum 45 (1970): 40-68; Philippe Contamine, “À l'abordage! Pierre de Brézé, grand sénéchal de Normandie, et la guerre de course (1452-1458)," in La Normandie et l'Angleterre au Moyen Age (Publications du CRAHM, 2003): 307-57. [Also cite recent work on Vitalienbruder and representative items for $18 \mathrm{C}$ privateering, and K. R. Andrews on Elizabethan Privateering...]

${ }^{8}$ C. J. Ford," Piracy or Policy: The Crisis in the Channel, 1400-1403," Transactions of the Royal Historical Society, $5^{\text {th }}$ series 29 (1979), pp. 63-77; Pistono, "Henry IV and the English Privateers, "322-330; idem, "Henry IV and John Hawley, Privateer, 1399-1408," Transactions of the Devonshire Association 110 (1979), pp. 14563. R. G. Marsden, "Early Prize Jurisdiction and Prize Law in England," English Historical Review 24 (1909): 675-97; D. A. Gardiner, "The History of Belligerent Rights on the High Seas in the Fourteenth Century," Law Quarterly Review 48 (1932): 521-46.

${ }^{9}$ Pistono, "Henry IV and the English Privateers," idem, "Henry IV and John Hawley." Gardiner (of D. A. Gardiner, "John Hawley of Dartmouth” Transactions of the Devonshire Association, 98 (1966) 173-205) and M. Jones ("Roches contre Hawley: la cour anglaise de chevalerie et un cas de piraterie à Brest, 1386-1402," Mémoires de la société d'histoire et de l'archéologie de Bretagne, 64 (1987), pp. 53-64) tend to avoid the issue of discerning piracy from privateering

${ }^{10}$ C. Richmond, "War at Sea," in C. T. Allmand, ed. The Hundred Years War, 96-121; idem "Keeping the Seas during the Hundred Years War, 1422-1440," History 49 (1964), 283-94; and note his other article on Warwick... See also below, p. 10. J. W Sherborne," Battle of La Rochelle and War at Sea 1372-5,"
} 
anything as privateering and tends to lump it with piracy of pointing to the possibilities of prizes in the sixteenth century. ${ }^{11}$

These works on English privateering are most useful for their ability to draw out the political and overall impact of privateering on maritime commerce, but they have less to say about how privateering actually worked, who was involved, and what the profits might have been, aside from some anecdotal information on a few episodes of privateering - particularly the flurry of activity in the early days of Henry IV (c. 1399-1403) and the late 1430s and 1440s, when Henry VI licensed whole groups of privateers. So when I began this project I started from scratch by reading through the primary sources that treat privateering, such as the Patent and Close Rolls, the Rolls of Parliament, Rymer's Foedera, and such TNA classes as Ancient Petitions (SC8), Issue Rolls (E403), Warrants for Issues (E404), various Diplomatic Documents (such as E30, Treasury of the Receipt), and Chancery Miscellanea (C47). The available material is immense and I have by no means exhausted what can be done; in fact, about half way through this project I realized that only a Ph.D. dissertation could do justice to what needs to be done.

Here is where I stumbled across my second problem. I thought I would recognize privateering when I saw it in medieval documents since I was well-acquainted with its definition: an armed vessel owned and crewed by private individuals but officially sanctioned by government authority — often with a letter of marque - to capture merchant shipping belonging to an enemy nation. ${ }^{12}$ In other words, privateering was government-sponsored legal piracy. But as soon as I attempted to start coding cases for the database I had constructed, I ran into a huge number of problems (not helped by the fact that medieval documents never use the word "privateering") and found myself having to think carefully about how to distinguish whether a particular incidence of prize or hostile attack was piracy, or privateering, or simply naval activity. What I want to do for the rest of this paper, therefore, is take advantage of the expertise in this audience to discuss my thinking on four possible types of privateering that I have come across in order to test whether I've made the right assessments or not.

${ }^{11}$ G. V. Scammell, "War at Sea under the Early Tudors-Part II," Archaeologica Aeliana, $4^{\text {th }}$ ser., 39 (1961), 179-205 [check his other articles]. For the Tudor period, see also Appleby, who focuses on lawlessness at sea and tends to not distinguish piracy from privateering during the late middle ages (see his "Devon privateering" and see his book?)

12 "privateer, . $^{2 "}$ The Oxford English Dictionary. 2nd ed. 1989. OED Online. Oxford University Press. 19 June 2008 http://dictionary.oed.com/cgi/entry/50188923. For modern scholarly definitions, see David Starkey , "Introduction," to Pirates and Privateers, ed. David Starkey et al. (1997); Osprey book on Pirates, 2007 pp. 
I started with what I thought would be the easiest way to identify privateering: by looking at grants of reprisal and letters of marque, many of which are recorded in the Patent Rolls. Most of the letters of marque are from the Crown, but a surprising number were issued by other authorities, including various Admirals, the Duke of Clarence as lieutenant of Ireland, the Prince of Wales, and even the steward of Gascony. Since many of the non-Crown authorizations survived because they were mentioned in disputes, and because these nonroyal sanctions were more common in the fourteenth than fifteenth century, it seems fair to conclude that they were simply a stage in the evolution of letters of marque, which-as Mollat and others have pointed out — became considerably more regularized and subject to common standards by the mid to late fifteenth century. My bigger problem was assessing how reprisals and letters of marque were executed. Stray references indicate that a good number were simply carried out by a local or crown official who arrested the enemy goods as they were found in or arrived at a port-no action at sea or privateering was involved. It is in fact a bit of a mystery how such letters of marque were publicized since most of the merchants who received them were in no position to personally seek out the intended targets at sea. Even when they were, the process by which they got their hands on the captured goods is unclear. For instance, Thomas Felde, a merchant of Salisbury-not exactly a port town-received letters from the Admiral in reply to his petition for compensation for $£ 400$ worth of goods plundered by Frenchmen at sea and, mistaking them for authorized reprisal, captured wine from a French ship in compensation, which the Admiral promptly confiscated as unlawful prize. ${ }^{13}$ How likely is it that Felde outfitted a ship, went to sea, and directed this capture himself? Not likely I think, but he may have funded the venture since he was held responsible for assuming his letters from the Admiral were legitimate letters of marque. Another inland merchant-Margery Russell, widow of John Russell of Coventry-received letters of marque from Henry IV against merchants of Santander in Spain for their failure to restore her ship and goods, valued at 1250 marks, that they illegally captured at sea. John Hawley of Dartmouth responded to this letter of marque by capturing wine from a Spanish balinger, although the seizure only happened to be recorded because Henry V rescinded Margery's letters in the interests of maintaining peace with the King of Spain. ${ }^{14}$ These examples raise several questions. How were letters of marque publicized? Once authorized, were copies sent as a matter of course to port town officials? Or, more likely, did the holder

\footnotetext{
${ }^{13}$ Rotuli parliamentroum, III, 512 [now cite new online edition]; TNA, SC8/22/1079.

${ }^{14}$ CPR 1413-16, 17-18, 35.
} 
of the marque make sure they were communicated to the right people, even to the extent of commissioning well-known and effective privateers such as Hawley to carry them out? What payment did privateers expect when they acted on someone else's letter of marque? Did the holders of marque fold the payout that privateers expected for their efforts into the other expenses that they were owed (letters of marque almost always included not only the original value of the captured goods, but also 'reasonable' legal costs and damages)? In the end, all the work I did tracking letters of marque and reprisal ended up as a bit of a dead end because it is so difficult to tell whether they actually were implemented via privateering - in fact, not many were I suspect, though I intend to keep looking for specific examples of successful letters of marque to determine whether they did do much to stimulate privateering.

The second path to privateering represents the most direct data: licenses granted by the Crown to attack the king's enemies at sea. The evidence is indeed excellent in that the licenses name specific shipowners and shipmasters, often list the ships to be involved, and set out the terms of service, which normally include the right to keep all of what they captured (unlike ships and men working for the king's wages, who were required to give a portion of what they captured to the king and/or admiral). The problem here is that there less than twenty or so such licenses survive in the materials I have examined, and the vast majority are in the period 1399-1403, when Henry IV had a conscious policy of employing privateers to harass enemy shipping — or in the period 1436-1441 when Henry VI followed a similar policy. ${ }^{15}$ It is clear that more such licenses were probably issued but are not extant, and that some kings in their haste to meet an enemy threat as quickly and inexpensively as possible (particularly Henry IV) issued general calls for fleets of privateers. ${ }^{16}$ It appears that formal licenses were not always necessary to attack the king's enemies in the fourteenth century, although they seem to have become more essential to carry on such activities by the fifteenth century. ${ }^{17}$ We discover the identity of these privateers primarily when they strayed over the line and attacked friendly shipping, which does tend to generate wonderfully detailed documentation, such as the long inquisitions that Stephen Pistono worked with for Flanders and Spain and C.J. Ford found in the French Archives Nationales. I am in the process of

\footnotetext{
15 [list typical examples] Also see CJ Ford, T. H. Lloyd, England and the German Hanse 1157-1611: A Study of Their Trade and Commercial Diplomacy (Cambridge, 1991); S. Pistono, and J. H. Wylie, "The Pirate War," in The Reign of Henry VI, for 1399-1403, and C. Richmond for 1436-41.

${ }^{16}$ For example, CPR 1399-1401, 349-50, 358; TNA, E403/571, m. 27...etc... For examples of privateering ventures that seem to lack licenses, see Devon Heritage Centre, Calendar of Deeds and Documents for Dartmouth, transcripts of Early Chancery Proceedings in DD 68292 (C1/8/14?)...

${ }^{17}$ Gardiner, "John Hawley of Dartmouth," 175, maintains that such licenses were not essential, but that seems to be the case more in the $14^{\text {th }}$ than $15^{\text {th }}$ century....
} 
entering these privateers into the database, but their numbers are relatively few-not many more than fifty — and they are mostly shipowners, victuallers, or shipowners, the top level of privateers. I suspect that most of the big-name privateers, such as John Hawley and Richard Spicer, were rarely personally involved at sea on privateering excursions, which makes it necessary to recognize separate categories of privateers, including the top-level men who financed these operations, the shipmasters and captains who directed activities at sea, and the common seamen and soldiers who accompanied these expeditions and received a share of the profits. A fourth category could be privateer leaders like Henry Pay of Poole and perhaps Mark Mixtow of Fowey who do seem to have personally led privateering expeditions. It is far easier to identify the financiers and shipmasters than the mariners involved, but the occasional survival of detailed inquisitions can provide useful insights, such as that for the alleged piracy at Brest when three ships of John Hawley attacked foreign vessels traveling under a safe-conduct from the captain of Brest in $1386 .{ }^{18}$ Well over seventy crew members gave depositions, forty-eight of whom identified themselves as mariners, along with fourteen who identified themselves primarily as artisans, including a carpenter, barber, cutler, plumber, and even a skinner. Almost all were from Devon (though two were from Cornwall and Southampton), and about three-quarters listed Dartmouth as their residence. Their average age was 30 when the incident occurred; nine were in their late 40s or older, but five of these were artisans or shipmasters. ${ }^{19}$ Further investigation of these types of inquisitions will do much to illuminate the role of common seamen in medieval English privateering.

The remaining two examples of privateering are more problematic, but instructive for what they can tell us. The third category concerns commissions to "safeguard the seas," or to guard the coast. Some of these are very early, such as the $1234 / 5$ order for six galleys to search for pirates off Sandwich. The problem here is that we lack details as to who paid these galleys; if they were paid by the crown, then technically they were not privateers, although they would be able to keep a portion of what they captured. These general orders to safeguard the sea are particularly plentiful for the fourteenth century, but more detailed for the fifteenth century, when specific terms of service were more likely to be recorded. It is difficult to tell, for example, whether the 1322 mandate to the bailiffs and good men of the

${ }^{18}$ TNA, C47/6/4. See also the comments of Gardiner, "John Hawley of Dartmouth," and Jones, "Roches contre Hawley." Prosopographical analysis was also employed to derive further details on these mariners.

19 For a longer discussion of these men, see Maryanne Kowaleski, "The Demography of Maritime Communities in Medieval England," in England in the Age of the Black Death: Essays in Honour of John Hatcher, ed. Mark Bailey and Stephen Rigby (Turnhout: Brepols, 2012), pp. 87-118. 
ports of Norfolk and Suffolk to provide ships and men at arms to set out to sea against the Flemings and others who were plundering English ships was a license to privateers, or simply a preliminary order for naval service at the king's expense. ${ }^{20}$ It will be necessary to find extant naval pay lists in such classes as TNA E101 to determine definitively whether these coast guard squadrons were privately run, or supervised and paid by the Crown. Another unclear case occurred in 1323, when mariners of south Kent who did coast guard off the Isle of Thanet were paid by a levy on men who remained at home, which we could consider a kind of proxy for Crown wages, especially since their rates of pay were the same offered to those in regular naval service. ${ }^{21}$ Coast guard could be dangerous work since it was usually ordered during war time when the threat of coastal raids was imminent; not surprisingly, this meant that there were plenty of prizes to be had from enemy shipping, or even from merchant ships who were perceived to be helping the enemy or carrying their goods. ${ }^{22}$ There are also a number of instances of vessels guarding the coast who were attacked by enemy ships, only to be rescued by other English ships on coast guard duty, which says something about how crowded the coastal waters could be during war time. ${ }^{23}$

Among the more interesting cases are those regarding petitions to the King and Council about the ineptitude of those ordered to do coast guard in the $1380 \mathrm{~s} .{ }^{24}$ The complaints targeted specific mariners, most from Winchelsea, who were appointed to safe-guard the sea, but did not do their job properly so that the petitioners' ships and goods were captured by the enemy. One petition noted that the mariners were only a mile away from where their ship was taken and could have come to their aid if they had wanted. ${ }^{25}$ Others claimed that the those on coast guard remained anchored in Orwell for almost three weeks, rather than being out at sea protecting English shipping. ${ }^{26}$ Yet others complained that they had been assured that they would be safe, but were chased by the enemy and captured. They were also charged with acting under a commission from the king but diverting their energies to transporting cargoes and even pilgrims instead of doing their duty to protect English ships. The Winchelsea mariners were paid what several petitioners grumbled was "a great sum of silver

${ }^{2}$ CPR 1321-4, 104.

${ }^{21}$ CCR 1323-7, 613.

${ }^{22}$ For example, Calendar of Inquisitions Miscellaneous, II, 529 (1324 case).

${ }^{23}$ E.g. n. 15, above, and CCR 1385-6, 167.

${ }^{24}$ TNA, SC8/214/10692, 10693, 10694, 10695, 10697, 10700, 10702, 10703, 10704, and below, notes 1922.

25 TNA, SC8/214/10696.

26 TNA, SC8/214/10698. 
and 6 pence in the pound and 2 shillings for each tun of wine," 27 The accused mariners responded that others involved in this duty had never been held responsible for such losses in the past. ${ }^{28}$ These arrangements suggest that they were paid by the king from special customs duties, and thus cannot be considered privateers. But their failures may also hint at why Henry IV turned so eagerly to private contractors from 1399 to 1403, the heyday of medieval English privateering.

This is the category that causes the most confusion amongst historians, who tend to label 'privateering' what is really commerce raiding under naval auspices. For example, the editor of the English Historical Documents titles one extract: "The commons asks for a fleet of privateers to keep the sea, 1442." But on reading the extract, which is from the Rolls of Parliament, it is clear that the Commons expected ships on naval service to provide protection, not private squadrons. Their request lays out in considerable detail the types, numbers, and fortifications of the ships to be included in the force; the wages, food, and rewards that the captains, quarter masters, shipmen and soldiers were to receive; and how the whole eight-month enterprise was to be funded: from a fourth-part of a half-fifteenth tax granted by the Commons. ${ }^{29}$ Although the document is in English, the word 'privateer' is never employed. Presumably the editor was persuaded to call this arrangement privateering because of the details set out on the division of prize, but in fact, such divisions were part and parcel of ordinary naval service and a matter of long-practiced custom and law by this period.

Confusion about this category of privateering is especially evident in the case of Richard Neville, Earl of Warwick, who Colin Richmond calls "the greatest privateer of his age." But if we examine the terms of Warwick's 1457 agreement with the king, this label may not be completely appropriate. ${ }^{30}$ Warwick agreed to be at sea from February through October for three years; to pay for his ships and their crews and soldiers, he was to receive the customs of tonnage and poundage from a variety of ports, plus $£ 1000$ a year from the revenues of the Duchy of Lancaster. His remuneration also included the right to keep all prizes he took. The promised funding from the Crown was, however, not always forthcoming, and so, the argument goes, Warwick interpreted his safeguarding of the seas rather liberally in capturing something like ten Spanish ships, two Genoese carracks, and up to seventeen Hanse salt

\footnotetext{
27 TNA, SC8/102/5066.

28 TNA, SC8/125/6221.

${ }^{29}$ English Historical Documents, 466-7; Rotuli parliamentorum, V, 59-60 [now cite new online edition].

${ }^{30}$ Richmond, "The Earl of Warwick's Domination of the Channel and the Naval Dimension to the Wars of the Roses, 1456-1460," Southern History, 20-21 (1988-89), 1-19; see also his "English Naval Power in the 15C" and "The Keeping of the Seas during the HYW..."
} 
ships. The capture of the Hanse ships, on the pretext that they refused to strike in the name of the king of England, was stepping over the limits of the indenture since they were friendly not enemy shipping. At this point Richmond (and Gerald Harris) call Warwick a pirate, though Richmond argues that Warwick had to pay his crews and the Calais garrison in some way when Crown funding did not materialize on time. I am less inclined to call Warwick a privateer or a pirate in this period, and his subsequent efforts to assemble a fleet once he split from the Lancastrian government is a matter of political perspective, since he was considered a rebel by Henry VII who commissioned various captains to hunt him down. By this time it was a case of two navies pitted against each other, although Warwick's "personal" fleet was, according to Richmond, essentially the foundation of the Yorkists' navy. At this point the whole exercise of distinguishing piracy, privateering, and naval activity becomes especially frustrating...

The fourth and last category of privateering concerns armed vessels and men for wine convoys or fishermen. Although armed escorts for the Bordeaux wine fleet were explicitly allowed to capture enemy goods at sea while on duty, in 1372 the sums they collected from captures or even side-line trading ventures were to be deducted from the two shillings charge on every tun of wine that the king assigned to pay for their services. ${ }^{31}$ I have not been able to discover the extent to which these convoys found profit in capturing enemy ships, but it's clear that the lure of further booty was supposed to provide incentive to convince shipowners to make the extra investment in arms and men that such duty required. The more intriguing example is wafting, ships hired to protect fishermen in the east coast fisheries (but sometimes the Irish and Icelandic fisheries), primarily against Scottish and French attacks from the midfifteenth into the sixteenth century. ${ }^{32}$ Although sponsored and sometimes organized by the Crown, the cost of protecting English fishermen was primarily thrust upon the fishers and fishing ports themselves. ${ }^{33}$ In 1379, six vessels were hired to protect fishing vessels were allowed to take six pence per tonight weekly from herring ships (and six pence quarterly from ships carrying coal from Newcastle), and six pence a last from other ships carrying

\footnotetext{
${ }^{31}$ R. G. Marsden, ed. Documents Relating to the Law and Custom of the Sea, vol. 1, A.D. 1205-1648 (Navy Records Society, 49, 1915), 92-3; citing Patent Rolls, 46 Edw III, m. 20.

${ }^{32}$ See M. Oppenheim, "Maritime History," in William Page (ed.), VCH Kent, II (London, 1926), 281; W. R. Childs, "Control, Conflict and International Trade," in Sea Fisheries of England and Wales, ed. David Starkey et al., 32; Kowaleski, "The Commercialization of Fishing in Medieval England and Wales," etc... For what may be a mid-fourteenth century example, see Bishop's Register of John de Grandisson, pp. 1547-8. For the Irish fisheries and voyage to the Icelandic fisheries, see Childs (on Hull's Icelandic trade?), 19

${ }^{33}$ For example: CPR 1476-85, 317, 322, 466, 487; 1485-94, 39, 347.
} 
merchandise from Prussia or Norway, ${ }^{34}$ but in 1469, Norfolk and Suffolk fishing ships were paying 10s to 20s each (plus fish on occasion) to the Duke of Norfolk for providing ships to protect them. ${ }^{35}$ There is evidence for all sorts of private arrangements between individual fishing ports and privateers; many of these contracts come to our notice only because the waftors exceeded their mandate by attacking friendly shipping or, in one case, a ship at anchor in Orwell. ${ }^{36}$ The lure of sanctioned plunder was clearly a spur for many since commissions to waftors from the Crown contain warnings to attack only the king's enemies. As time went on, moreover, the language of these commissions began to include orders to arrest those who presumed to be guards, conveyors or waftors, a sign that the authorization of the Crown was a desirable cover for plunder at sea. The Crown's success in controlling waftors' entrepreneurial activities by the very end of the fifteenth century seems, however, to have dampened enthusiasm for wafting, since orders to impress sailors and soldiers for wafting start to appear in the 1490 s and continue into the sixteenth century. ${ }^{37}$

In conclusion, I hope I have shown that constructing a typology of medieval privateering is an essential first step towards gathering further data on this type of commerce raiding. Although the legitimate captures made by waftors and ships on wine convoy duty, or by those sailing under letters of marque, or given license to hunt down the king's enemies at sea, or authorized to safeguard the sea or guard the coast may be harder to locate in our documentation than illegal captures and piracy, they are worth pursuing for the information they can offer about this most enterprising of all maritime ventures. Contemporaries, moreover, recognized the distinction between privateering and piracy, as is evident from their understanding of the rules regarding the division of prize - which varied according to whether one was on naval service, or operating under a privateering license, or engaged in outright piracy - and from the measures that the Crown had to keep coming up with to counteract the inventive subterfuges of those who knew that the line between privateering and piracy could be a dangerous one to cross. The profits from piracy could be large and alluring, but the transactions costs could be crippling; the gains from privateering were just as lucrative as those of piracy, and the transactions costs lower in terms of potential legal

\footnotetext{
${ }^{34}$ Rotuli parliamentorum, III, 63, 391 [cite new online edition and check for who paid to]. See also Chronicon Angliae, 170.

${ }^{35}$ Anne Crawford, ed., The Household Books of John Howard, Duke of Norfolk, 1462-71, 1481-83 (Stroud, 1992), xxxv-Xxxvi.

${ }^{36}$ CPR 1467-77, 318 [check], cited in VCH Essex, 267. Note too that sometimes ' $k$ keeping the sea' was combined with protecting fishermen; see, for example, $C P R$ 1413-16, 363-4.

${ }^{37}$ CPR 1485-94, 347; and see Marsden, Documents, I. pp.
} 
expenses and the need to find buyers for illegal goods and ships. There were well-established protocols for selling goods and ships captured legitimately; the New Romney and Dover records use the term skomerfare or skumerie to refer to the private initiative that lay behind answering the king's call to fight his enemies at sea. ${ }^{38}$ The income that mariners could collect from their portion of prize, such as the $£ 46 \mathrm{~s} 8 \mathrm{~d}$ listed among the debts owed to the mariner Thomas Langston as his portion of herring taken at sea, needs to be considered as an important revenue source for many common seamen. Because such ventures were legal and not a particularly unusual feature of port life along the southern coast of England in the tumultuous fourteenth and fifteenth centuries, they are harder to identify in our extant records. By continuing my work on the database of privateers, however, I hope to continue to build a picture of this important part of the maritime economy and society of medieval England.

${ }^{38}$ Register of Daniel Rough, ed. K. M. Murray (Kent Record Society), 128, n. 1, 157. See also 1358 in S. P. H. Statham Dover Charters (1902) 86 . Que bona et quanta cepissent per Skomerfare, tempore quo dictus Custos optinuerit ballivam suam. Note also this reference from online MED, 1390 under GOWER, conf. III 321: "Out of a barge faste by, Which hidd was ther on Scomerfare, Men sterten out" Note, however, that the word stems from the same root as skumer, which means sea rover-or pirate (see OED). 